\title{
Antioxidative factors in milk
}

\author{
Helena Lindmark-Månsson ${ }^{1,2} *$ and B. Åkesson ${ }^{2}$ \\ ${ }^{1}$ Swedish Dairy Association, Scheelevägen 18, SE-223 63 Lund, Sweden \\ ${ }^{2}$ Division of Biomedical Nutrition, Center for Chemistry and Chemical Engineering, Lund University, SE-221 00 Lund, \\ Sweden
}

\begin{abstract}
Lipid auto-oxidation in milk is affected by a complex interplay of pro- and antioxidants. Several of these compounds are also important nutrients in the human diet and may have other physiological effects in the gastrointestinal tract and other tissues. Among antioxidative enzymes superoxide dismutase catalyses the dismutation of superoxide anion to hydrogen peroxide. The degradation of hydrogen peroxide can be catalysed by catalase and the selenoprotein glutathione peroxidase. The latter enzyme can also degrade lipid peroxides. Lactoferrin may have an important role by binding pro-oxidative iron ions. The occurrence of different forms of these antioxidative proteins in milk and available data on their functional role are reviewed. More remains to be learnt of individual compounds and as an example the potential role of seleno compounds in milk is virtually unknown. Antioxidative vitamins in milk can provide an important contribution to the daily dietary intake. Moreover vitamin $\mathrm{E}$ and carotenoids act as fat-soluble antioxidants, e.g. in the milk fat globule membrane, which is regarded as a major site of auto-oxidation. Vitamin $\mathrm{C}$ is an important water-soluble antioxidant and interacts in a complex manner with iron and fat-soluble antioxidants. The concentrations of these compounds in milk are affected by cow feeding rations and milk storage conditions. Since milk contains a number of antioxidants many reactions are possible and the specific function of each antioxidant cannot easily be defined. There are indications that other compounds may have antioxidative function and measurement of total antioxidative capacity should be a useful tool in evaluating their relative roles.
\end{abstract}

Antioxidative enzymes: Milk: Vitamins: Lactoferrin

\section{Introduction}

Milk lipids can undergo auto-oxidation, which may lead to changes in food quality. The mechanisms involved include a complex interplay of pro- and antioxidants consisting both of low-molecular-weight compounds, such as vitamins, and proteins. Moreover, the physical-chemical orientation of different compounds in milk has a pronounced influence.

Antioxidants can function by a number of mechanisms. Different enzymes can prevent the formation of radicals or scavenge radicals or hydrogen peroxide and other peroxides. Other enzymes catalyse the synthesis or regeneration of non-enzymatic antioxidants. Among antioxidant enzymes, superoxide dismutase and catalase have been demonstrated in milk. Another enzyme family with antioxidant functions are the selenium-containing glutathione peroxidases (GSHPx). They catalyse the reduction of different peroxides aided by glutathione or other reducing substrates.

Non-enzymatic antioxidants can be formed in the animal body or need to be supplied in the feed as essential nutrients. The iron-binding protein lactoferrin can act as an antioxidant, and vitamin $\mathrm{C}$ (ascorbic acid) and vitamin $\mathrm{E}$ (tocopherols and tocotrienols) are antioxidant vitamins. Some carotenoids have provitamin A action but they also have antioxidant functions. Several non-enzymatic antioxidants act as radical scavengers in the lipid phase, such as vitamin $\mathrm{E}$, carotenoids and ubiquinol whereas vitamin $\mathrm{C}$ acts in the water phase. Others can react in both the lipid and the water phase, such as some flavonoids, which operate both as radical scavengers and metal ion binders. Moreover, the dietary supply of some B vitamins and trace elements is important for optimal activity of several antioxidant enzymes. Foods can also contain added natural or synthetic antioxidants. This report reviews the occurrence and functional aspects of antioxidants in bovine milk.

\section{Antioxidative enzymes in milk}

Superoxide dismutase (SOD)

SOD catalyses the dismutation of superoxide anion to hydrogen peroxide:

$$
2 \mathrm{O}_{2}^{--}+2 \mathrm{H}^{+} \rightarrow \mathrm{H}_{2} \mathrm{O}_{2}+\mathrm{O}_{2}
$$


There are three types of SOD which contain either manganese, copper/zinc or iron (Fridovich, 1986) and in bovine milk Cu/Zn-SOD is found (Asada, 1976; KoryckaDahl et al. 1979). The enzyme in milk serum has the same specific activity, molecular weight and electrophoretic properties as bovine erythrocyte $\mathrm{Cu} / \mathrm{Zn}$-SOD (Hill, 1975; Asada, 1976; Korycka-Dahl et al. 1979). In human milk the activity of Mn-SOD has also been identified (Kiyosawa et al. 1993).

Bovine SOD is a dimer with a molecular weight of 31$33 \mathrm{kDa}$ (Evans et al. 1974). Each monomer contains approximately 153 amino acids, one disulphide bridge, one $\mathrm{Cu}^{2+}$ ion and one $\mathrm{Zn}^{2+}$ ion. The $\mathrm{Cu}^{2+}$ is located in the active site and is responsible for electron transfer during action of the enzyme (Fridovich, 1974). The $\mathrm{Cu}^{2+}$ is partially exposed to the solvent, but the $\mathrm{Zn}^{2+}$ is wholly buried within the protein structure and is thought to play a structural role, aiding protein stability (Rotilio et al. 1972).

SOD has been partly purified from skim milk after precipitation of casein with rennet (Hill, 1975). The whey was concentrated, the solution was treated with ethanol and chloroform and the precipitated proteins were removed by centrifugation. SOD was purified from the supernatant by gel chromatography and ion exchange chromatography (Hill, 1975). SOD is absent in cream and only found in skim milk (Asada, 1976). The activity of SOD detected in milk corresponds to between $0.15 \mathrm{mg}$ (Hill, 1975) and $2.4 \mathrm{mg}$ of enzyme per litre milk when compared to the activity of purified bovine erythrocyte SOD (Korycka-Dahl et al. 1979). The concentration of SOD in milk varies between cows and breeds. The average activity of SOD in milk serum from Holsteins was $0.92 \mathrm{U} / \mathrm{ml}$ and from Jerseys $1.27 \mathrm{U} / \mathrm{ml}$ (Hoolbrook \& Hicks, 1978) and in milk from Ayrshire cows the activity was $0.89 \mathrm{U} / \mathrm{ml}$ (Kankare \& Antila, 1982).

The concentration of SOD in cow's milk is probably not affected by stage of lactation or age of the cow, and does not vary between morning and night milking. Neither is it affected by high somatic cell counts (Hicks, 1980). The concentration of SOD in milk is approximately 100 times lower than that in bovine blood (Hoolbrook \& Hicks, 1978). The SOD concentration in human milk is 2.0 to 2.3 times higher than that of bovine milk (Kiyosawa et al. 1993)

$\mathrm{Cu} / \mathrm{Zn}$-SOD is very resistant to various types of denaturing stress including heating. In fact commercial pasteurised milk retains the enzymatic activity at a similar level to unpasteurised milk (Asada, 1976). A minimal pasteurisation $\left(71.7^{\circ} \mathrm{C}\right.$ for $\left.15 \mathrm{~s}\right)$ does not cause heat inactivation of SOD but heat treatments at $>75^{\circ} \mathrm{C}$ have been shown to inactivate more than $20 \%$ of the SOD. Purified SOD fractionated from bovine milk is more sensitive to thermal processing than the SOD in bovine milk serum (Hicks et al. 1979; Korycka-Dahl et al. 1979).

The most commonly used assay of SOD in milk is based on measuring the inhibition of the reduction of cytocrome $c$ by the superoxide anion, produced enzymatically in the xanthine-xanthine oxidase (XO) reaction (Asada, 1976; Korycka-Dahl et al. 1979). Since endogenous XO occurs in the milk and may interfere with the SOD determination, an improved method has been developed in which $\mathrm{XO}$ is reduced by ultrafiltration in the samples prior to analysis (Granelli et al. 1994).

\section{Catalase}

Catalase catalyses the decomposition of hydrogen peroxide:

$$
2 \mathrm{H}_{2} \mathrm{O}_{2} \rightarrow 2 \mathrm{H}_{2} \mathrm{O}+\mathrm{O}_{2}
$$

Catalase is a large enzyme, containing haem-bound iron in its active site. Catalase has a very high capacity to destroy $\mathrm{H}_{2} \mathrm{O}_{2}$ and in terms of molecules of $\mathrm{H}_{2} \mathrm{O}_{2}$ degraded per minute per molecule of enzyme, it is one of the most active enzymes known (Gutteridge \& Halliwell, 1994). The catalase molecule is usually composed of four identical $60 \mathrm{kDa}$ subunits, with a total molecular weight in the region of $240 \mathrm{kDa}$, containing four moles of protohaem (Shonbaum \& Chance, 1976; Ito \& Akuzawa, 1983a; Robinson, 1991). Catalase has been purified from bovine milk by several purification steps, including n-butanol extraction, ammonium sulphate treatment, ethanol-chloroform fractionation, DEAE-Sephacel column chromatography and Sephacryl S-300 gel filtration (Ito \& Akuzawa, 1983a). Optimum $\mathrm{pH}$ and temperature for enzyme activity are $\mathrm{pH} 8.0$ and $20^{\circ} \mathrm{C}$ (Ito \& Akuzawa, 1983a).

Cream contains about $60 \%$ and skim milk about $40 \%$ of the milk catalase. Most of the catalase in the cream is bound firmly to the membranes of fat globules and cannot be released readily into skim milk. Milk contains three types of catalase that are different from one another with respect to chromatographic and electrophoretic mobility whereas the two types in cream have similar immunological characteristics (Ito \& Akuzawa, 1983b; Ito et al. 1984). Other data by Kitchen et al. (1970) have indicated that skim milk contains $73 \%$ of the whole milk activity and cream $24 \%$.

The average catalase activity in raw milk, determined by a polarographic method, was $1.95 \mathrm{U} / \mathrm{ml}$. Catalase concentrations in raw milk samples have been found to be higher in April than in November, indicating a seasonal variation (Hirvi \& Griffiths, 1998). The activity of catalase in normal milk is generally lower than in mastitic bulk milk (Kitchen et al. 1970), which agrees with the findings that catalase activity correlated positively to somatic cell count (Read et al. 1969).

Catalase is one of the most heat-labile enzymes occurring in milk, with most of the activity being destroyed by treatment at $72^{\circ} \mathrm{C}$ for $15 \mathrm{~s}$ (Ito \& Akuzawa, 1983a; Griffiths, 1986; Hirvi \& Griffiths, 1998). However, reactivation with a greater than 20 -fold increase in activity, was observed in milk which had been first heated at $80^{\circ} \mathrm{C}$ for $15 \mathrm{~s}$ and then stored at $4^{\circ} \mathrm{C}$ for $24 \mathrm{~h}$. Since catalase is also present within leucocytes and bacteria this can possibly be explained by its protection from denaturation by heat within cells and its subsequent release during storage of the pasteurised product causing an apparent reactivation (Griffiths, 1986).

A method for determining catalase by a disk-flotation procedure has been described. This method is based on the liberation of oxygen due to the action of catalase on hydrogen peroxide (Gagnon et al. 1959). Catalase activity 
can also be assayed by the polarographic method in which oxygen released from $\mathrm{H}_{2} \mathrm{O}_{2}$ is quantitated with an oxygen electrode (Hirvi et al. 1996).

\section{Glutathione peroxidase}

Glutathione peroxidase removes $\mathrm{H}_{2} \mathrm{O}_{2}$ and other peroxides at a high rate. Its seleno group is oxidised by the peroxide and then reduced by glutathione (GSH), which is converted into oxidised glutathione (GSSG) (Gutteridge \& Halliwell, 1994).

$$
2 \mathrm{GSH}+\mathrm{H}_{2} \mathrm{O}_{2} \rightarrow \mathrm{GSSG}+2 \mathrm{H}_{2} \mathrm{O}
$$

The first report of glutathione peroxidase activity was made by Mills (1957) who demonstrated glutathione-dependent catabolism of $\mathrm{H}_{2} \mathrm{O}_{2}$ by bovine red cell lysate. Selenium was discovered to be an essential component of glutathione peroxidase (GSHPx) in 1973 (Flohé et al. 1973). Four gene-products are classified as members of the seleniumdependent GSHPx family. The most well known are the cellular or classical GSHPx and the plasma or extracellular GSHPx, which are homotetrameres. Selenium is specifically incorporated into proteins as selenocysteine in response to the opal codon UGA. It can also be incorporated as selenomethionine. Selenocysteine is part of the active site of glutathione peroxidases (Ladenstein $e t$ al. 1979; Ren et al. 1997).

The bovine plasma GSHPx has been cloned and contains 226 amino acids with a calculated subunit weight of $24860 \mathrm{Da}$. The corresponding amino acid sequence showed an overall identity of $88 \%$ with the human plasma GSHPx, $88.5 \%$ with the rat plasma GSHPx, but only $46.4 \%$ with the cellular bovine glutathione peroxidase (Martín-Alonso et al. 1993).

GSHPx activity has been detected in raw cow's milk, at levels between 12 and $32 \mathrm{U} / \mathrm{ml}$ and its activity correlates significantly with selenium concentration. This suggests that GSHPx is one of the biologically active forms of selenium in cow's milk (Hojo, 1982; Debski et al. 1987). Both GSHPx activity and selenium contents of human milk have been shown to decrease with time of lactation and reach a plateau at one month postpartum (Hojo, 1986).

The percentage of total peroxidase activity associated with glutathione peroxidase has been reported as $29 \%$, $27 \%$ and $65 \%$ for human, cow's and goat milk, respectively. The GSHPx activity in human milk is at the same level as in bovine milk, 31-39 U/ml (Hojo, 1986; Debski et al. 1987; Bhattacharya et al. 1988). Most of the glutathione peroxidase activity has been found in the fractions corresponding to $150-170$ and $92-96 \mathrm{kDa}$ in milk from all species examined. These results suggest that a substantial portion of the GSHPx in milk exists in a complex form attached to high-molecular-weight proteins within the casein fraction (Debski et al. 1987; Bhattacharya et al. 1988). For human milk most of the activity corresponds to fractions containing proteins with molecular weights of approximately $92 \mathrm{kDa}$. The monomer weight was estimated to be $23 \mathrm{kDa}$ indicating that the native enzyme consists of four identical subunits. The selenium content of the purified enzyme was $0.31 \%$ (Bhattacharya et al. 1988). The GSHPx purified from human plasma showed the same characteristics (Takahashi et al. 1987).

Human milk glutathione peroxidase has been purified 4500 -fold using acetone precipitation and purification by repetitive ion-exchange and gel filtration chromatography (Bhattacharya et al. 1988). Of the GSHPx activity in human milk $90 \%$ could be precipitated by anti-plasma-GSHPx immunoglobulin G. Thus, most if not all GSHPx activity in human milk is due to the plasma form of the enzyme (Avissar et al. 1991). In two human milks $4 \%$ and $13 \%$ of total selenium was calculated to be bound to GSHPx (Avissar et al. 1991).

Only a few studies have been made on the heat stability of GSHPx. When heating milk at $80^{\circ} \mathrm{C}$ for $10 \mathrm{~min}$ no activity remained and no activity of GSHPx could be detected in market-pasteurised milk (Hojo, 1982). The effect of milder heat treatment is not known.

GSHPx activity is usually measured by the coupled assay of Paglia \& Valentine (1967) or modifications thereof. It is an indirect assay, which requires a peroxide source and a coupled reaction maintaining the concentration of the initial GSH substrate. The GSHPx activity is quantified indirectly in a sample by its ability to cause an increased rate of loss of NADPH compared to the rate of loss seen in a reagent blank.

Although GSHPx is an important seleno compound in milk, other such compounds may also be antioxidative. Recently, it has been found that several seleno compounds may scavenge peroxynitrite radicals (Sies et al. 1997), but the role of this reaction in milk has not been studied. The mean selenium concentration in bovine milk varied in European studies between 3.9 and $23.2 \mathrm{mg} / 1$ (Alaejos \& Romero, 1995) and in Swedish bulk milk $18 \mathrm{mg} / \mathrm{kg}$ was found (Lindmark-Månsson, unpublished results). In milks from the United States and Australia extreme values of 64 and $0.2 \mathrm{mg} / \mathrm{l}$, respectively, have been reported. The importance of these wide variations in selenium for the antioxidative properties of milk remains to be elucidated.

\section{Non-enzymatic antioxidants in milk}

\section{Lactoferrin}

Lactoferrin is an $80 \mathrm{kDa}$ iron-binding glycoprotein occurring in whey. It is composed of a single polypeptide chain with two binding sites for ferric ions. Also the plasma ironbinding protein transferrin occurs in milk of some species. There is marked species variation and an inverse relationship between the concentrations of lactoferrin and transferrin. In bovine milk their concentration is in the range 20-200 mg/l each. In bovine milk lactoferrin can bind approximately five times more iron than is naturally present. Several functions have been proposed for lactoferrin, including: iron-binding, a role in iron absorption, bacteriostatic or bacteriocidal action, and a role as a growth factor (Renner et al. 1989; Hambraeus \& Lönnerdal, 1994). Binding of iron to lactoferrin may decrease the conversion of hydrogen peroxide into hydroxyl radical via the Fenton type of reaction. In model experiments bovine lactoferrin was found to inhibit the oxidation of ascorbic acid and tryptophan (Bihel \& Birlouez-Aragon, 1998). Antioxidant 
activity of lactoferrin has been observed in other model systems (Gutteridge et al. 1981; Shinmoto et al. 1992). The role of lactoferrin is reviewed elsewhere in this volume (Steijns \& van Hooijdonk).

\section{Vitamin $C$}

Ascorbic acid can easily be oxidised to dehydroascorbic acid, especially at alkaline $\mathrm{pH}$. Dehydroascorbic acid can either be further oxidised or reconverted into ascorbic acid by an enzyme catalysed reaction. Under some conditions ascorbic acid can act as a pro-oxidant by regenerating the perferryl radical at initiation of lipid peroxidation.

Andersson \& Öste (1994) found that in unpasteurised milk sampled in March or August the concentration of ascorbic acid was higher $(20-27 \mathrm{mg} / \mathrm{l})$ than in samples collected in October $(12 \mathrm{mg} / \mathrm{l})$. Lindmark-Månsson (unpublished results) found a mean of $11.6 \mathrm{mg}$ of vitamin $\mathrm{C} / \mathrm{kg}$ bulk milk in Sweden, $10 \cdot 2 \mathrm{mg} / \mathrm{kg}$ consisting of ascorbic acid and $1.4 \mathrm{mg} / \mathrm{kg}$ of dehydroascorbic acid and also found higher values of vitamin $\mathrm{C}$ in July and September than in January and March.

Several groups have analysed vitamin $\mathrm{C}$ in milk after heat treatment. Bilic (1991) measured both ascorbic and dehydroascorbic acid and found a concentration of ascorbic acid in raw milk of $5.9 \mathrm{mg} / \mathrm{l}$ and in pasteurised milk $4.0 \mathrm{mg} / \mathrm{l}$, in ultra heat treated (UHT) milk by indirect heating $0 \cdot 1-1 \cdot 1 \mathrm{mg} / 1$ and UHT milk by direct heating $3.9-$ $4.2 \mathrm{mg} / \mathrm{l}$. The corresponding concentrations of dehydroascorbic acid in raw milk was $1.5 \mathrm{mg} / \mathrm{l}$ and in pasteurised milk $0.4 \mathrm{mg} / \mathrm{l}$, in UHT milk by indirect heating $0 \cdot 1-$ $0.2 \mathrm{mg} / \mathrm{l}$ and UHT milk by direct heating $0.3 \mathrm{mg} / \mathrm{l}$. Pizzoferrato (1992) found that the retention of ascorbic acid was higher after pasteurisation at $80-85^{\circ} \mathrm{C}$ than at $72-$ $75^{\circ} \mathrm{C}$ and $90^{\circ} \mathrm{C}$, and that UHT treatment at $140^{\circ} \mathrm{C}$ caused lower values than pasteurisation. Vahcic et al. (1992) found that in raw bulk milk the ascorbic acid concentration was $14 \mathrm{mg} / \mathrm{l}$, in pasteurised milk $9 \mathrm{mg} / \mathrm{l}$ and in sterilised milk $6 \mathrm{mg} / \mathrm{l}$.

With respect to storage effects Andersson \& Öste (1994) found no notable loss in ascorbic acid during storage of pasteurised milk in a domestic type refrigerator for one week. The same group (Andersson \& Öste, 1992a,b) also followed the ascorbic acid concentration during storage at different temperatures of UHT milk prepared with different oxygen content. In milk with the lowest oxygen content (0.6 p.p.m.) ascorbic acid decreased to half of its original concentration after 1-2 weeks with somewhat higher stability at $7^{\circ} \mathrm{C}$ than at $23^{\circ} \mathrm{C}$ and $35^{\circ} \mathrm{C}$. At oxygen contents of 3.5-5.4 p.p.m. the loss was much more rapid.

Thus, the vitamin $\mathrm{C}$ level in milk can be markedly influenced both by storage and heating conditions. Also Korhonen \& Korpela (1994) concluded that vitamin C and several other water-soluble vitamins are lost during storage and heating of milk whereas fat-soluble vitamins are more stable.

\section{Vitamin $E$}

Vitamin E consists of eight vitamers and $\alpha$-tocopherol is the major one in bovine milk. $\alpha$-Tocopherol is an important lipid-soluble antioxidant and acts as a radical scavenger. The tocopheryloxy radical formed is relatively stable and can be reconverted into tocopherol by reduction with ascorbic acid. Different authors have reported concentrations of $\alpha$-tocopherol between 0.2 and $0.7 \mathrm{mg} / \mathrm{l}$ in bovine milk (Jensen, 1995). $\gamma$-Tocopherol has also been demonstrated and trace amounts of some other vitamers. Barrefors et al. (1995) reported $\alpha$-tocopherol levels of 7.4-10.0 mg/g lipid for different herds and also demonstrated low levels of $\alpha$-tocotrienol. Lindmark-Månsson (unpublished results) found $1.0 \mathrm{mg} / \mathrm{kg}$ of $\alpha$-tocopherol in Swedish bulk milk with a mean fat content of $4.3 \%$. Colostrum was shown to contain $1.9 \mathrm{mg} / \mathrm{l}$ of $\alpha$-tocopherol decreasing in approximately four days to the level in fresh milk, $0.3 \mathrm{mg} / \mathrm{l}$ (Hidiroglou, 1989).

Several reports on the effect of $\alpha$-tocopherol supplementation on milk oxidative stability have emerged. Supplementation of cows after one month of lactation with $5 \mathrm{~g}$ DL- $\alpha$-tocopherol intraperitoneally was shown to increase milk $\alpha$-tocopherol five times and the values remained higher than the original ones for six days (Hidiroglou, 1989). Also intravenously administrated DL$\alpha$-tocopherol was found to increase both milk and plasma $\alpha$-tocopherol levels. St-Laurent et al. (1990) supplemented Holstein cows for five weeks with 0,700 or 3000 IU per day of $\alpha$-tocopherol given in a grain mix. In the group given $3000 \mathrm{IU} /$ day milk $\alpha$-tocopherol increased from 0.55 to $0.8 \mathrm{mg} / \mathrm{l}$ but the level declined to presupplementation levels by two weeks after treatment. In that study, the effects on milk flavour of $\alpha$-tocopherol supplementation to a feed consisting of grain mix, hay and pasture were also investigated in herds with a chronic spontaneous oxidised flavour milk problem. $\alpha$-Tocopherol supplementation improved milk flavour but there was no relationship between milk $\alpha$-tocopherol levels and degree of flavour improvement. After the supplementation period all cows got access to spring pasture and then the flavour problem decreased markedly. The same research group also made a study on supplementation with $\alpha$-tocopherol together with inorganic selenium mixed in the concentrate ration or alfalfa enriched by spraying with selenium before ensiling (Nicholson et al. 1991). There was no significant effect of $\alpha$-tocopherol or selenium supplementation on spontaneous oxidation flavour but $\alpha$-tocopherol inhibited the generation of copper-catalysed oxidised flavour. The data also suggested that selenium supplementation improved the transfer of dietary $\alpha$-tocopherol to milk. Use of higher levels of $\alpha$-tocopherol supplementation or parenteral injection modes gave more clear improvement of milk oxidative stability (Charmley \& Nicholson, 1993; Charmley et al. 1993). Nicholson \& St-Laurent (1991) also found that supplementation with $\alpha$-tocopherol to a corn silage feed was more effective in improving milk oxidative stability than the supplementation to an alfalfa silage feed.

The demands on milk oxidative stability and vitamin $\mathrm{E}$ levels increase when cows are fed unsaturated fats to modify milk fatty acid composition. Feeding of rations containing rapeseed were found to increase the proportion of monoenoic fatty acids in milk fat and also its vitamin $\mathrm{E}$ content which could explain the prolonged induction time for milk fat oxidation (Flachowsky et al. 1997). Use of 


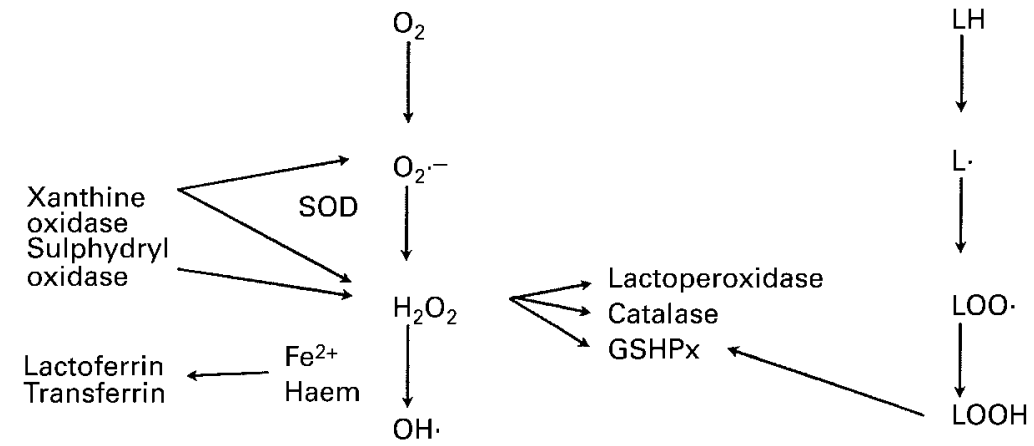

Fig. 1. Proposed action of some pro- and antioxidant proteins in milk. The left vertical reaction sequence includes oxygen, superoxide anion, hydrogen peroxide and hydroxyl radical. The right vertical reaction sequence includes unsaturated fatty acid, lipid radical, peroxyl radical and fatty acid hydroperoxide.

rapeseed expellers instead decreased the milk vitamin $\mathrm{E}$ level and decreased the induction time for oxidation. Another group (Focant et al. 1998) added extruded rapeseed and linseed to cow feed, which increased the content of unsaturated fatty acids and vitamin $\mathrm{E}$ in milk but decreased its resistance to oxidation. Supplementation with approximately 10000 IU of $\alpha$-tocopherol per day further increased the milk $\alpha$-tocopherol levels and also the resistance to milk oxidation.

An interesting explanation for the difficulties in finding simple relationships between milk $\alpha$-tocopherol concentration and its susceptibility to oxidation was advanced by Jensen \& Nielsen (1996). At normal rations the content of $\alpha$-tocopherol per $g$ fatty acid is higher in the milk fat globule membrane than in cream, and the membrane fraction also contains a higher proportion of unsaturated fatty acids. On the other hand $\gamma$-tocopherol and $\beta$-carotene are only found in cream. At low concentrations of $\alpha$ tocopherol in milk fat, however, the decrease in $\alpha$ tocopherol content is more rapid in the milk fat globule membrane than in cream making the former fraction more susceptible to oxidation.

With respect to storage Vidal-Valverde et al. (1993) found that $\alpha$-tocopherol in UHT milk stored at $30^{\circ} \mathrm{C}$ decreased by $3-14 \%$ at one month and by $9-30 \%$ at two months. The losses were marginally higher after storage at $40^{\circ} \mathrm{C}$ or $50^{\circ} \mathrm{C}$. After storage of UHT milk at $-20^{\circ} \mathrm{C} \alpha$ tocopherol levels were stable for two months but decreased by $10-21 \%$ after four to eight months.

\section{Carotenoids}

Like tocopherols, carotenoids are fat-soluble compounds and their concentration is influenced by the total fat concentration in dairy products. They function as singlet oxygen scavengers and may also react with other reactive oxygen species. Lindmark-Månsson (unpublished results) has found $0.20 \mathrm{mg} / \mathrm{kg}$ of $\beta$-carotene in bulk milk with a mean fat content of $4.3 \%$. Ollilainen et al. (1989) found $0.17 \mathrm{mg} / \mathrm{kg}$ of $\beta$-carotene in whole milk (3.9\% fat) and $0.10 \mathrm{mg} / \mathrm{kg}$ in milk with $1.9 \%$ fat. Only traces of lutein and other carotenoids were demonstrated. Khackik et al. (1997) in a detailed study identified thirty-four carotenoids in human milk. To our knowledge no corresponding investigation has been made for bovine milk.

Barrefors et al. (1995) reported $\beta$-carotene levels of 3.5$4.9 \mathrm{mg} / \mathrm{g}$ fat in milk with and without off-flavour in different herds. For some herds $\beta$-carotene and/or $\alpha$ tocopherol levels were lower in milks with off-flavour but this finding was not consistent. In a supplementation study (Schweigert \& Eisele, 1990) a single intravenous or intramuscular injection of 100 or $500 \mathrm{mg} \beta$-carotene to cows was shown to increase milk $\beta$-carotene from $0.02-$ $0.05 \mathrm{mg} / \mathrm{l}$ to $0.13-0.16 \mathrm{mg} / \mathrm{l}$ and the maximum was attained approximately one week after injection. With respect to carotenoid stability during storage Ruas-Madiedo et al. (1998) found that addition of carbon dioxide to milk followed by storage at $4^{\circ} \mathrm{C}$ for one week after pasteurisation had little influence on the concentrations of $\beta$-carotene and $\alpha$-tocopherol.

\section{Interaction among antioxidants}

Free radicals can react with unsaturated fatty acids, proteins, DNA and other compounds and cause different types of damage, but some free radicals have positive biological functions. Free radicals vary much with respect to reactivity and a hierarchy or a pecking order can be predicted (Buettner, 1993). The interaction of vitamin E and vitamin $\mathrm{C}$ is compatible with this hierarchy. However, many reactions are possible, and the specific function of each antioxidant cannot easily be defined. The occurrence of many antioxidants has led to the development of methods to measure total antioxidant capacity. Korpela et al. (1995) found that cow's milk had both peroxyl radical trapping capacity and superoxide radical trapping capacity. More work is necessary to identify the most active antioxidant compounds in milk.

Still another way of comparing oxidation in milk-related solutions has been used by Champagne et al. (1990) who investigated the formation of ascorbate free radicals in ascorbic acid-fortified milk and related products. They found that the formation of radicals increased in the following order: ascorbic acid-fortified milk $<$ ascorbic acid solution $<$ milk - or soy-based infant formula $<$ ascorbic acid solution containing iron and copper $<$ 
infant formula containing iron and copper. In all solutions radical formation increased with increasing $\mathrm{pH}$. Several compounds in cow's milk may thus inhibit the production of ascorbic acid radicals.

Furthermore, the susceptibility to lipid oxidation may be affected after fortification of milk by vitamin $\mathrm{C}$ and iron since both ascorbic acid at high concentration and iron may be pro-oxidative. Rosenthal et al. (1993) found no evidence for this since addition of ascorbic acid $(1 \mathrm{~g} / \mathrm{l})$ with or without iron lactate $(50 \mathrm{mg} / \mathrm{l})$ or iron lactate alone to raw milk had no significant effect on lipid oxidation, as assessed by formation of free fatty acid or thiobarbituric acid-reactive substances.

An attempt has been made to integrate some available information on pro- and antioxidant proteins in milk (Fig. 1). The reduction of oxygen to oxygen reactive species is indicated on the left. Hydrogen peroxide can be produced by sulphydryl oxidase and xanthine oxidase, and xanthine oxidase may also give rise to superoxide. Superoxide dismutase catalyses the formation of hydrogen peroxide from superoxide. The conversion of hydrogen peroxide into the hydroxyl radical can be controlled by the availability of iron ions, influenced by lactoferrin and transferrin. Moreover, hydrogen peroxide can be consumed in reactions catalysed by lactoperoxidase, catalase and glutathione peroxidase.

The oxidation of an unsaturated lipid is summarised to the right. By different reactions lipoperoxides $(\mathrm{LOOH}) \mathrm{can}$ be formed, such as fatty acid hydroperoxides and phospholipid hydroperoxides, which can be reduced by different glutathione peroxidases. At present we do not have a good overview on the relative importance of all these reactions and more studies are necessary to achieve this goal. One regulatory factor is the availability of different enzyme substrates, and this may vary in milks of different origins and after different treatments.

\section{Conclusions}

Oxidative reactions in milk are affected by a complex interplay of pro- and antioxidants. Since many antioxidants can be found in milk several reactions are possible and the specific function of each antioxidant cannot easily be defined at present. A deeper understanding of these mechanisms may lead to optimised milk handling and processing procedures as well as a better assessment of the importance of milk antioxidants in human health.

\section{References}

Alajos MS \& Romero CD (1995) Selenium concentration in milks. Food Chemistry 52, 1-18.

Andersson I \& Öste R (1992a) Loss of ascorbic acid, folacin and vitamin B12, and changes in oxygen content of UHT milk. I. Introduction and methods. Milchwissenschaft 47, 223-224.

Andersson I \& Öste R (1992b) Loss of ascorbic acid, folacin and vitamin B12, and changes in oxygen content of UHT milk. II. Results and discussion. Milchwissenschaft 47, 299-302.

Andersson I \& Öste R (1994) Nutritional quality of pasteurized milk. Vitamin $\mathrm{B}_{12}$, folacin and ascorbic acid content during storage. International Dairy Journal 4, 161-172.
Asada K (1976) Occurrence of superoxide dismutase in bovine milk. Agricultural Biology and Chemistry 40, 1659-1660.

Avissar N, Slemmon JR, Palmer IS \& Cohen HJ (1991) Partial sequence of human plasma glutathione peroxidase and immunological identification of milk glutathione peroxidase as the plasma enzyme. Journal of Nutrition 121, 1243-1249.

Barrefors P, Granelli K, Appelqvist L- $\AA$ \& Björck L (1995) Chemical characterization of raw milk samples with and without oxidative off-flavor. Journal of Dairy Science 78, 2691-2699.

Bhattacharya ID, Picciano MF \& Milner JA (1988) Characteristics of human milk glutathione peroxidase. Biological Trace Element Research 18, 59-70.

Bihel S \& Birlouez-Aragon I (1998) Inhibition of tryptophan oxidation in the presence of iron-vitamin $\mathrm{C}$ by bovine lactoferrin. International Dairy Journal 8, 637-641.

Bilic N (1991) Assay of both ascorbic and dehydroascorbic acid in dairy foods by high-performance liquid chromatography using precolumn derivatization with methoxy- and ethoxy-1,2phenylenediamine. Journal of Chromatography 543, 357-374.

Buettner GR (1993) The pecking order of free radicals and antioxidants: lipid peroxidation, $\alpha$-tocopherol, and ascorbate. Archives of Biochemistry and Biophysics 300, 535-543.

Champagne ET, Hinojosa O \& Clemetson CAB (1990) Production of ascorbate free radicals in infant formulas and other media. Journal of Food Science 55, 1133-1136.

Charmley E \& Nicholson JWG (1993) Injectable $\alpha$-tocopherol for control of oxidized flavour in milk from dairy cows. Canadian Journal of Animal Science 73, 381-392.

Charmley E, Nicholson JWG \& Zee JA (1993) Effect of supplemental vitamin $\mathrm{E}$ and selenium in the diet on vitamin $\mathrm{E}$ and selenium levels and control of oxidized flavor in milk from Holstein cows. Canadian Journal of Animal Science 73, 453457.

Debski B, Piccano MF \& Milner JA (1987) Selenium content and distribution of human, cow and goat milk. Journal of Nutrition 117, 1091-1097.

Evans HJ, Steinmann HM \& Hill RL (1974) Bovine erythrocyte superoxide dismutase. Isolation and characterisation of tryptic, cyanogen bromide and maleyated tryptic peptides. Journal of Biological Chemistry 249, 7315-7325.

Flachowsky G, Schaarmann G, Jahreis G, Schöne F, Richter GH, Böhme H \& Schneider A (1997) Einfluss der Vefütterung von Ölsaaten und Nebenprodukten aus Ölsaaten auf die Vitamin EKonzentration in Tierprodukten. Fett/Lipid 99, 55-60.

Flohé L, Günzler WA \& Schock HH (1973) Glutathione peroxidase: a selenoenzyme. FEBS Letters 32, 132-134.

Focant M, Mignolet E, Marique M, Clabots F, Breyne T, Dalemans D \& Larondelle Y (1998) The effect of vitamin E supplementation of cow diets containing rapeseed and linseed on the prevention of milk fat oxidation. Journal of Dairy Science 81, 1095-1101.

Fridovich I (1974) Superoxide dismutases. Advances in Enzymology 41, 35-97.

Fridovich I (1986) Superoxide dismutases. Advances in Enzymology 58, 61-97.

Gagnon M, Hunting WM \& Esselen WB (1959) New method for catalase determination. Analytical Chemistry 31, 144-146.

Granelli K, Björck L \& Appelqvist L- $\AA$ (1994) The variation of superoxide dismutase (SOD) and xanthine oxidase (XO) activities in milk using an improved method to quantitate SOD activity. Journal of the Science of Food and Agriculture 67, 85-91.

Griffiths MW (1986) Use of milk enzymes as indices of heat treatment. Journal of Food Protection 49, 696-705.

Gutteridge JMC \& Halliwell B (1994) Antioxidants in Nutrition, Health and Disease. Oxford: Oxford University Press. 
Gutteridge JMC, Paterson SK, Segal AW \& Halliwell B (1981) Inhibition of lipid peroxidation by the iron-binding protein lactoferrin. Biochemical Journal 56, 2079-2080.

Hambraeus L \& Lönnerdal B (1994) The physiological role of lactoferrin. In Proceedings of the IDF Seminar, Indigenous Antimicrobial Agent of Milk, pp. 97-107. Brussels: International Dairy Federation.

Hicks CL (1980) Occurrence and consequence of superoxide dismutase in milk products: a review. Journal of Dairy Science 63, 1199-1204.

Hicks CL, Bucy J \& Stofer W (1979) Heat inactivation of superoxide dismutase in bovine milk. Journal of Dairy Science 62, 529-532.

Hill RD (1975) Superoxide dismutase activity in bovine milk. Australian Journal of Dairy Technology 30, 26-28.

Hidiroglou M (1989) Mammary transfer of vitamin E in dairy cows. Journal of Dairy Science 72, 1067-1071.

Hirvi Y \& Griffiths MW (1998) Milk catalase activity as an indicator of thermization treatments used in the manufacture of cheddar cheese. Journal of Dairy Science 81, 338-345.

Hirvi Y, Griffiths MW, McKellar RC \& Modler HW (1996) Linear-transform and non-linear modelling of bovine milk catalase inactivation in a high-temperature short-time pasteurizer. Food Research International 29, 89-93.

Hoolbrook JJ \& Hicks CL (1978) Variation of superoxide dismutase in bovine milk. Journal of Dairy Science 61, 1072-1077.

Hojo Y (1982) Selenium concentration and glutathione peroxidase activity in cows milk. Biological Trace Element Research 4, 233-239.

Hojo Y (1986) Sequential study on glutathione peroxidase and selenium contents of human milk. Science of the Total Environment 52, 83-91.

Ito O \& Akuzawa R (1983a) Purification, crystallisation and properties of bovine milk catalase. Journal of Dairy Science $\mathbf{6 6}$, 967-973.

Ito O \& Akuzawa R (1983b) Isozymes of bovine milk catalase. Journal of Dairy Science 66, 2468-2473.

Ito O, Akuzawa R \& Kamata S (1984) Immunochemical differences between two types catalase from cows milk cream. Japanese Journal of Zootechnical Science 55, 722-727.

Jensen RG (1995) Fat-soluble vitamins in bovine milk. In Handbook of Milk Composition, pp. 718-725 [RG Jensen, editor]. San Diego: Academic Press.

Jensen SK \& Nielsen KN (1996) Tocopherols, retinol, $\beta$-carotene and fatty acids in fat globule membrane and fat globule core in cow's milk. Journal of Dairy Research 63, 565-574.

Kankare V \& Antila V (1982) The effect of xanthine oxidase and superoxide dismutase as well as cell counts on the oxidation of fat in bovine milk. Finnish Journal of Dairy Science 2, 32-40.

Khachik F, Spangler CJ, Smith JC Jr, Canfield LM, Steck A \& Pfander H (1997) Identification, quantification, and relative concentrations of carotenoids and their metabolites in human milk and serum. Analytical Chemistry 69, 1873-1881.

Kitchen BJ, Taylor GC \& White IC (1970) Milk enzymes - their distribution and activity. Journal of Dairy Research 37, 279288.

Kiyosawa I, Matuyama J, Nyui S \& Yoshida K (1993) Cu, Znand $\mathrm{Mn}$ - superoxide dismutase concentration in human colostrum and mature milk. Bioscience, Biotechnology and Biochemistry 57, 676-677.

Korhonen H \& Korpela R (1994) The effects of dairy processes on the components and nutritional value of milk. Scandinavian Journal of Nutrition 38, 166-172.

Korpela R, Ahotupa M, Korhonen H \& Syväoja E-L (1995) Antioxidant properties of cow's milk. In Proceedings of the NJF/NMR Seminar no. 252, pp. 157-159, Turku, Finland.
Korycka-Dahl M, Richardson T \& Hicks CL (1979) Superoxide dismutase activity in bovine milk serum. Journal of Food Protection 42, 867-871.

Ladenstein R, Epp O, Bartels K, Jones A, Huber R \& Wendel A (1979) Structural analysis and molecular model of the selenoenzyme glutathione peroxidase at $2.8 \mathrm{~A}$ resolution. Journal of Molecular Biology 134, 199-218.

Martín-Alonso J-M, Ghosh S \& Coca-Prados M (1993) Cloning of the bovine plasma selenium-dependent glutathione peroxidase (GP) cDNA from the ocular ciliary epithelium: expression of the plasma and cellular forms within the mammalian eye. Journal of Biochemistry 114, 284-291.

Mills GC (1957) Hemoglobin catabolism. I. Glutathione peroxidase, an erythrocyte enzyme which protects hemoglobin from oxidative breakdown. Journal of Biological Chemistry 229, 189-197.

Nicholson JWG \& St-Laurent A-M (1991) Effect of forage type and supplemental dietary vitamin E on milk oxidative stability. Canadian Journal of Animal Science 71, 135-143.

Nicholson JW, St-Laurent A-M, McQueen RE \& Charmley E (1991) The effect feeding organically bound selenium and $\alpha$ tocopherol to dairy cows on susceptibility of milk to oxidation. Canadian Journal of Animal Science 71, 1181-1186.

Ollilainen V, Heinonen M, Linkola E, Varo P \& Koivistoinen P (1989) Carotenoids and retinoids in Finnish foods: dairy products and eggs. Journal of Dairy Science 72, 2257-2265.

Paglia DE \& Valentine WN (1967) Studies on the quantitative and qualitative characterization of erythrocyte glutathione peroxidase. Journal of Laboratory and Clinical Medicine 70, 158169.

Pizzoferrato L (1992) Examples of direct and indirect effects of technological treatments on ascorbic acid, folate and thiamine. Food Chemistry 44, 49-52.

Read RB, Reyes AL, Bradshaw JG \& Peeler JT (1969) Evaluation of seven procedures for detection of abnormal milk due to mastitis. Journal of Dairy Science 52, 1359-1367.

Ren B, Huang W, Ákesson B \& Ladenstein R (1997) The crystal structure of seleno-glutathione peroxidase from human plasma at $2.9 \AA$ resolution. Journal of Molecular Biology 268, 869885.

Renner E, Schaafsma G \& Scott KJ (1989) Micronutrients in milk. In Micronutrients in Milk and Milk-based Food Products, pp. 1-70 [E Renner, editor]. London: Elsevier Science Publishers.

Robinson DS (1991) Peroxidases and catalases in foods. In Oxidative Enzymes in Foods [DS Robinson and NAM Eskin, editors]. London: Elsevier Science Publishers Ltd.

Rosenthal I, Rosen B \& Bernstein S (1993) Effect of milk fortification with ascorbic acid and iron. Milchwissenschaft $\mathbf{4 8}$ 676-679.

Rotilio G, Calabrese L, Bossa F, Barra D, Finazzi Agró A \& Mondovi B (1972) Properties of the apoprotein and role for copper and zinc in protein conformation and enzyme activity of bovine superoxide dismutase. Biochemistry 11, 2182-2192.

Ruas-Madiedo P, Bascarán V, Braña AF, Bada-Gancedo JC \& de los Reyes-Gavilán CG (1998) Influence of carbon dioxide addition to raw milk on microbial levels and some fat-soluble vitamin contents of raw and pasteurized milk. Journal of Agricultural and Food Chemistry 46, 1552-1555.

Schweigert FJ \& Eisele W (1990) Parenteral beta-carotene administration to cows: effect on plasma levels, lipoprotein distribution and secretion in the milk. Zeitschrift für Ernährungswissenschaft 29, 184-191.

Shinmoto H, Dosako S \& Nakajima I (1992) Anti-oxidant activity of bovine lactoferrin on iron/ascorbate induced lipid peroxidation. Bioscience, Biotechnology and Biochemistry 56, 20792080.

Shonbaum GR \& Chance B (1976) Catalase. In The Enzymes, vol. 
XIII, pp. 363-408 [PD Boyer, editor]. New York: Academic Press.

Sies H, Sharov V, Klotz L-O \& Briviba K (1997) Glutathione peroxidase protects against peroxynitrite-mediated oxidations. Journal of Biological Chemistry 272, 27812-27817.

St-Laurent A-M, Hidiroglou M, Snoddon M \& Nicholson JWG (1990) Effect of $\alpha$-tocopherol supplementation to dairy cows on milk and plasma $\alpha$-tocopherol concentrations and on spontaneous oxidized flavor in milk. Canadian Journal of Animal Science 70, 561-570.
Takahashi K, Avissar N, Whitin J \& Cohen HJ (1987) Purification and characterization of human plasma glutathione peroxidase: a selenoglycoprotein distinct from known cellular enzyme. Archives of Biochemistry and Biophysics 256, 677-686.

Vahcic N, Palic A \& Ritz M (1992) Mathematical evaluation of relationships between copper, iron, ascorbic acid and redox potential of milk. Milchwissenschaft 47, 228-230.

Vidal-Valverde C, Ruiz R \& Medrano A (1993) Effects of frozen and other storage conditions on $\alpha$-tocopherol content of cow milk. Journal of Dairy Science 76, 1520-1525. 